\title{
Benefits and Costs of the Informal Sector: The Case of Brick Kilns in Bangladesh
}

\section{Lelia Croitoru*, Maria Sarraf}

World Bank, Washington DC, USA.

Email: *1croitoru@worldbank.org

Received March 29 ${ }^{\text {th }}, 2012$; revised April 23 $3^{\text {rd }}, 2012$; accepted May 24 $4^{\text {th }}, 2012$

\begin{abstract}
In developing countries, the informal sector-brick kilns, leather tanning, food processing factories-is often highly polluting, causing countless deaths and illnesses. This paper presents the case of brick kilns in Dhaka, one of the most polluted cities in Asia. Five months per year, brick kilns are the city's main source of fine particulate pollution, accounting for 38 percent of total fine particulate mass. The paper values the impacts of existing and alternative brick kiln technologies in Dhaka city. Through a Cost-Benefit Analysis, it estimates the net returns for the entrepreneur, and the social costs, such as health impacts from air pollution and damages due to carbon emissions from kilns. It shows that cleaner technologies are more attractive than traditional technologies both from the private and social perspective, and provides concrete recommendations for a cleaner brick sector in Bangladesh.
\end{abstract}

Keywords: Cost-Benefit Analysis; Air Pollution

\section{Introduction}

The informal sector-small-scale, unlicensed and virtually unregulated firms - is important for the economies of developing countries, accounting for 50 to 80 percent of employment and 20 to 40 percent of output [1]. In India, for example, the informal sector absorbed more than 70 percent of total workforce in 2000 , based on data from National Sample Survey Organization [2]. However, a large proportion of the sector conducts highly polluting activities, such as leather tanning, textiles, food processing, metalworking and brick making. This pollution causes severe impacts, particularly on health, through deaths and illnesses, and environment, through reduced visibility and property value [3].

Brick making is a significant activity in Bangladesh, albeit not formally recognized as an industry ${ }^{1}$ [4]. With about 5000 operating kilns, brick making contributes about 1 percent to the country's gross domestic product and generates employment for about 1 million people [5]. The country is highly dependent on bricks for construction, primarily because of lack of stones. Construction industry has been rapidly rising at 5.6 percent per year, which led brick sector to grow annually at an estimated 2 -

\footnotetext{
${ }^{*}$ Corresponding author.

${ }^{1}$ This is because brick kilns are seasonal operations that do not provide year-round employment, while small and medium enterprises in Bangladesh are defined in terms of employment provided. Second, most brick kilns are located on rented land and do not have fixed assets (except for the chimney).
}

3 percent over the next decade [6].

Despite this importance, the vast majority of kilns use outdated, energy intensive technologies that are highly polluting. About 530 brick kilns are clustered north of Dhaka. During the dry season ${ }^{2}$, they are city's main source of fine particulate pollution and are responsible for 38 percentof the total fine particulate mass, followed by motor vehicles (19 percent) and road dust (18 percent) [7]. As Dhaka is one of the most polluted cities in the world $([8,9])$ addressing the impact of emissions from kilns and finding alternative options is very important.

This paper estimates for the first time the benefits and costs of current and alternative technologies in Bangladesh. Similar studies are lacking in most developing countries; only one comprehensive study on this issue has been found in Mexico [3]. Therefore, the present analysis offers a framework and lessons for other developing countries where pollution from kilns is a major problem.

\section{Selected Technologies}

The brick cluster north of Dhaka includes 530 kilns that produce about 2.1 billion bricks [5]. Most of them are Fixed Chimney Kilns (FCKs), which are located on lowlands. They usually burn low-quality coal imported

\footnotetext{
${ }^{2}$ This extends from November to April, which coincides with the kilns' operating period.
} 
from India with a high sulfur (about 5 percent) and clinker content. As a result, these kilns are very energyintensive and highly polluting. In 2010, Bangladesh issued a notification banning operation of FCKs three years from this date. However, transformative development in this sector is yet to occur.

Newer technologiesbring substantial improvements to the FCKs. For example, the Improved Fixed Chimney Kilns (IFCKs) use internal fuel, back-process mechanization, improved firing and operating practices, gravity settling chambers or scrubbers [10].

The Vertical Shaft Brick Kilns (VSBK) is a smallscale technology that operates year-round in highlands and uses green bricks with internal fuel ${ }^{3}$. A standard VSBK consists of two shafts, which produce 8000 10,000 bricks per day. A larger production facility can be built by adding more shafts.

The Hybrid Hoffmann Kilns (HHKs) is a hybrid version of the Hoffmann kiln technology developed in Germany in the mid- $19^{\text {th }}$ century. Unlike the gas-based Hoffmann kiln, the HHK uses coal as fuel. It combines fuel injection and external firing in highly insulated kilns. The HHK design combines a highly efficient kiln technology, known as Forced Draft Tunnel Kiln (FDTK), with a unique technique of forming green bricks: granulated coal is injected for internal combustion ${ }^{4}$. These improvements make these technologies less energy intensive and polluting than the FCKs $([11,12])$.

Several World Bank projects are introducing these technologies in Bangladesh. Thus, it is important to demonstrate their financial and economic viability. The paper addresses this issue by focusing on the four technologies discussed above and using the following assumptions:

- FCK. Based on a field survey of kiln owners, the FCK produces about 4 million bricks over a 5-month season.

- IFCK. Brick production can run from as low as 4 million (i.e., same as the FCK) to as high as 5.8 million bricks $^{5}$. This analysis conservatively assumes that the IFCK produces 4 million bricks.

\footnotetext{
${ }^{3} \mathrm{Up}$ to 50 percent of the pulverized coal is mixed in with clay. Internal fuel may include waste materials with some calorific value. The rest of the coal is charged along with the green bricks in the loading process. As the coal is stationary and enters the hot combustion zone slowly, it tends to burn out completely, providing higher efficiency and less pollution than a FCK.

${ }^{4}$ Nearly 80 percent of the total energy required is injected into the bricks while the remainder is fed externally into the firing chamber. Most of the fuel injected into the green bricks is completely burned during firing This technology improves energy efficiency in two ways: i) internal combustion of injected fuel in green bricks and ii) application of heat optimization techniques in a minimum heat-loss chamber in the kiln's combustion zone to capture waste heat for recirculation in the drying tunnel.

${ }^{5}$ Calculated based on a seasonal increase to 6 months (resulting from use of molders), a quantity of 16,000 bricks per day, and 30 days of work per month.
}

- VSBK. Based on a production of 16,000 bricks per day, 360 working days per year and 83 percent capacity utilization, the average production of a four-shaft VSBK is estimated at 4.8 million bricks per year [12].

- HHK. Based on a production of 50,000 bricks per day, 360 working days per year and 83 percent capacity utilization,the average production of a single-sized HHK is 15 million bricks per year [12].

\section{Methodology}

Estimating the net returns from each technology is based on the Cost-Benefit Analysis (CBA) approach. The analysis measures the net returns from the private and social perspectives, defined as follows (Table 1):

The private $C B A$, or the analysis from the entrepreneur's viewpoint, includes all direct costs and benefits for the entrepreneur. Costs cover investments (e.g., cost of buildings and kiln chimney, land, other inputs, and taxes), while benefits comprise the value of brick production. The costs and benefits are estimated at market prices.

The social CBA, or the analysis from the social viewpoint, includes costs and benefits from the previous step, as well as the environmental and social impacts of brick kilns, such as the health impact of air pollution and the cost of carbon dioxide $\left(\mathrm{CO}_{2}\right)$ emissions. The costs and benefits from the previous step are estimated at real (economic) prices, by eliminating taxes and other distortions. The cost of $\mathrm{CO}_{2}$ emissions are estimated based on the emissions and the carbon price from recent Clean Development Mechanism projects in Bangladesh.

The health impacts from pollution are valued based on the Disability Adjusted Life Years (DALYs) method. It provides a common measure of the disease burden for various illnesses and premature mortality [13]. The monetary valuation of 1 DALY is based on two approaches: 1) the human capital approach (HCA), which estimates it as a person's average contribution to production or the gross domestic product per capita [14], and 2) the Value of Statistical Life, which is based on willingness to pay to avoid death by observing individual behavior when trading off health and monetary risks [15]. In addition, the study captures the direct costs of illness, such as treatment costs.

The analysis refers to the year 2009 and uses a discount rate of 10 percent. The kilns' lifetime is 20 years for FCK, IFCK and VSBK and 10 years for HHK. Thus, the analysis uses a time horizon of 20 years and accounts for two production cycles of the HHK.

\section{Results}

The next sections present the results of the private and social CBA for each type of kiln and express them as net 
Table 1. Valuation methods to estimate the costs and benefits related to kilns in Bangladesh.

\begin{tabular}{cll}
\hline Analysis type & \multicolumn{1}{c}{ Costs and benefits } & Valuation method \\
\hline \multirow{2}{*}{ Private } & $\begin{array}{l}\text { Costs: } \\
\text { Investment, land, buildings, operating costs, taxes } \\
\text { Benefits: } \\
\text { alue of bricks }\end{array}$ & Market prices \\
& Costs: & Market prices \\
& Investment, land, buildings, operating costs & \\
& Health impact of air pollution & Real prices \\
& $\mathrm{CO}_{2}$ emissions & Disability Adjusted Life Years (DALYs) \\
Social & Benefits: & Priceon carbon market \\
& Value of bricks & Real prices \\
\hline
\end{tabular}

returns per 1000 bricks, in Bangladeshi Taka (US \$1 = TK70). The analysis uses secondary data, complemented by a field survey of kiln owners conducted in 2009 .

\subsection{Private Cost-Benefit Analysis}

The private CBA includes the direct costs and benefits to the entrepreneur. Direct costs comprise of the investment, e.g. kiln and other machineries; and annual costs, e.g. the rental value of land, operating costs (coal, water, soil, labor) and taxes. HHK has the highest cost because of its advanced technology and largest brick production. It provides also the largest benefits from the sale of highquality bricks (Table 2). Thus, the HHK is the most profitable technology for the entrepreneur, with TK116 per thousand bricks, in present value terms.

The net benefits from the other technologies are relatively lower and within the same range, of TK103108 per thousand bricks. The value of bricks is higher for VSBK and IFCK, primarily because of the larger proportion of high quality bricks they provide. The overall costs of FCK are the highest, due to greater coal consumption per unit of brick and cost of unskilled labor.

Overall, the HHK is the most profitable technology for the entrepreneur, while the other technologies are relatively profitable.

\subsection{Social Cost-Benefit Analysis}

The social CBA includes the direct costs and benefits; the health impacts from pollution related to particulate matter $\left(\mathrm{PM}_{2.5} \text { and } \mathrm{PM}_{10}\right)^{6}$; and the cost of $\mathrm{CO}_{2}$ emissions from the brick sector.

\subsubsection{Direct Costs and Benefits}

The market prices used for estimating the direct costs and benefits are not distorted (e.g., subsidized), thus they can be considered economic or real prices. Therefore, the social CBA includes all costs and benefits estimated for

${ }^{6} \mathrm{PM}_{2.5}$ is the particulate matter smaller than 2.5 microns in diameter; $\mathrm{PM}_{10}$ is the particulate matter smaller than 10 microns in diameter. the private $\mathrm{CBA}$, and excludes taxes.

\subsubsection{Health Impacts from Air Pollution}

We estimate the following health impacts of air pollution derived from kilns ${ }^{7}$ :

1) infant and child mortality from respiratory diseases caused by short-term $\mathrm{PM}_{10}$ exposure,

2) adult mortality from cardiopulmonary diseases and lung cancer caused by long-term $\mathrm{PM}_{2.5}$ exposure,

3) all-age morbidity resulting from $\mathrm{PM}_{10}$ exposure.

Valuation is based on the four steps presented below:

Step 1. Identify the pollutants and measure their concentration. This step estimates the contribution of each technology to the average $\mathrm{PM}_{2.5}$ and $\mathrm{PM}_{10}$ ambient air concentrations in Dhaka.

Contribution of the FCKs. The $\mathrm{PM}_{10}$ ambient concentration averages $150.5 \mu \mathrm{g}$ per $\mathrm{m}^{3}$, based on daily measurements, according to the Department of Environment ${ }^{8}$. It is reported that brick kilns in the cluster north of Dhaka contribute two-fifths of the measured fine particulates during the five-month operating period [17]. Using a source apportionment model, other authors estimate that brick kilns are the most important source of pollution, with fine-fraction particulates accounting for 38 percent of total mass, during kiln operation ${ }^{9}$ [7]. Applying this range, the annual contribution of the FCKs to the ambient $\mathrm{PM}_{10}$ concentration in Dhaka is estimated within 14 - 36 $\mu \mathrm{g}$ per $\mathrm{m}^{3}$, or $25 \mu \mathrm{g}$ per $\mathrm{m}^{3}$ on average.

Contribution of the IFCK, VSBK and HHK. As most kilns in the in the cluster north of Dhaka are FCKs, the contribution of the IFCKs, VSBKs, and HHKs to the city's average $\mathrm{PM}_{10}$ concentration cannot be measured. Table 3 estimates the emissions of suspended particulate

${ }^{7}$ See [32] for a more detailed discussion on the impact of air pollution on health.

${ }^{8} \mathrm{PM}$ values are monitored on a 24 -hour average basis; however data are not available for all days in a month, and the number of days per month for which data are monitored is also unequal.

${ }^{9}$ Other contributors to fine-particulate pollution include motor vehicle (19 percent), road dust (18 percent), soil dust ( 9 percent), metal smelter (7 percent), Zn source ( 7 percent), and sea salt (2 percent). 
Table 2. Results of the private cost-benefit analysis (present value, 20 years, 10\%, 2009).

\begin{tabular}{|c|c|c|c|c|}
\hline & FCK & IFCK & VSBK & HHK \\
\hline \multicolumn{5}{|l|}{ Basic information about kilns } \\
\hline Area occupied by kiln (bigha) & 15 & 15 & 4 & 12 \\
\hline Investment cost (TK million) & 4 & 8 & 7 & $47^{\mathrm{a}}$ \\
\hline Coal consumption ( $\mathrm{t} / 100,000$ bricks) & $20-24$ & $13-16$ & 13 & 13 \\
\hline Annual production (million bricks) & 4 & 4 & 5 & 15 \\
\hline High-quality bricks (\% of total production) & $50-75$ & $60-80$ & 95 & 85 \\
\hline Costs (million TK/kiln) (1) & 119 & 109 & 106 & 386 \\
\hline Investment & 4 & 7 & 6 & 56 \\
\hline Land & 1 & 1 & 1 & 3 \\
\hline Buildings & 0 & 0 & 1 & 9 \\
\hline Operations & 109 & 95 & 92 & 300 \\
\hline Taxes & 5 & 5 & 6 & 19 \\
\hline Benefits (million TK/kiln) (2) & 198 & 200 & 214 & 746 \\
\hline Net benefit (2-1) & 79 & 91 & 109 & 360 \\
\hline Net benefit (TK/thousand bricks) & 103 & 107 & 108 & 116 \\
\hline
\end{tabular}

Sources: field survey in 2009 and [5] for FCK and IFCK; [10-12,16] for VSBK and HHK. ${ }^{a}$ In addition, investments in HHK improvement include TK16 million in the $11^{\text {th }}$ cycle of production. Notes: 1 bigha $=407 \mathrm{~m}^{2} ;$ US $\$ 1=$ TK70.

Table 3. Estimated emission load of suspended particulate matter by kiln.

\begin{tabular}{|c|c|c|c|c|c|c|}
\hline $\begin{array}{l}\text { Kiln } \\
\text { type }\end{array}$ & $\begin{array}{l}\text { Production capacity } \\
\text { (million bricks/kiln) }\end{array}$ & $\begin{array}{l}\text { Number of kilns } \\
\text { needed to produce } \\
2.1 \text { bil. bricks }\end{array}$ & $\begin{array}{c}\text { SPM emission } \\
\text { load (kg/10,000 } \\
\text { bricks) }\end{array}$ & $\begin{array}{l}\text { SPM emission load } \\
\text { from producing } 2.1 \\
\text { bil. bricks }\end{array}$ & $\begin{array}{l}\text { Contribution to average } \\
\mathrm{PM}_{10} \text { concentration }(\mu \mathrm{g} \\
\left.\text { per } \mathrm{m}^{3}\right)\end{array}$ & $\begin{array}{c}\text { Contribution to average } \\
\mathbf{P M}_{2.5} \text { concentration }(\mu \mathrm{g} \\
\left.\text { per } \mathbf{~ m}^{3}\right)\end{array}$ \\
\hline FCK & 4 & 530 & $17.1^{\mathrm{a}}$ & 3.6 & 25 & 15 \\
\hline IFCK & 4 & 530 & $8.6^{\mathrm{b}}$ & 1.8 & 12.5 & 7.5 \\
\hline VSBK & 4.8 & 442 & $5.6^{\mathrm{c}}$ & 1.2 & 8.2 & 4.9 \\
\hline HHK & 15 & 140 & $8.7^{\mathrm{d}}$ & 1.8 & 12.7 & 7.6 \\
\hline
\end{tabular}

Sources: ${ }^{\mathrm{a}}[16,25] ;{ }^{\mathrm{b}}$ Based on emissions-load data for the FCK and [5] for the ratio in stack emissions between the FCK and the IFCK; ${ }^{\mathrm{c}}$ Based on measurements of SPM for 4 VSBKs in India [26] and 2 VSBKs in Nepal [27]; ${ }^{\mathrm{d}}[16]$ for HHK.

matter (SPM) from each kiln type, assuming that total brick production from the northern brick-kiln cluster $(2.1$ billion bricks) could be obtained by replacing the 530 FCKs with 530 IFCKs, or 442 VSBKs or 140 HHKs. The data represent measurements of emissions per brick available in Bangladesh (for FCK, IFCK and HHK), and Nepal and India (for VSBK). We assume that the pollution concentration at a receptor site is proportional to the emission rate ${ }^{10}$. Consequently, the contribution to the $\mathrm{PM}_{10}$ concentration is estimated at $12.5 \mu \mathrm{g}$ per $\mathrm{m}^{3}$ for the IFCKs, $8.2 \mu \mathrm{g}$ per $\mathrm{m}^{3}$ for the VSBKs and $12.7 \mu \mathrm{g}$ per $\mathrm{m}^{3}$ for the HHKs. We use a factor of 0.6 to convert $\mathrm{PM}_{10}$ levels to $\mathrm{PM}_{2.5}$ levels [20].

\footnotetext{
${ }^{10}$ Estimating these contributions is difficult, because it depends on several factors, such as: total emissions from each kiln, kiln type, dispersion patterns of these emissions, location of kilns, etc. Use of elaborate dispersion models accounting for all these factors can produce an accurate estimation of these contributions. In lack of these data, it is assumed that pollution concentration at a receptor site is proportional to the emission rate $([18,19])$.
}

Step 2. Estimate the population exposed. No accurate information is available on the population exposed to $\mathrm{PM}_{10}$ and $\mathrm{PM}_{2.5}$ from the brick industry. This is estimated by multiplying the total population of 12.8 million in the metropolitan Dhaka area [21] by a coefficient of exposure. It is sometimes argued that all people in Dhaka are exposed to these pollutants due to north-south winds during the brick season. ${ }^{11}$ Because of data uncertainty, it is assumed that about 90 percent of Dhaka's total population, or 11.5 million is exposed.

Step 3. Use dose-response functions. The health impacts on mortality and morbidity are valued based on dose-response functions developed in the international scientific literature and presented in Table 4. Based on these functions, the $\mathrm{PM}_{10}$ and $\mathrm{PM}_{2.5}$ emissions from the current 530 FCKs lead to 750 premature deaths per year. Alternatively, emissions from $442 \mathrm{VSBKs}$ would result in 260 premature deaths and emissions from $140 \mathrm{HHKs}$

\footnotetext{
${ }^{11}$ Personal communication with I. Hossain, September 2009.
} 
Table 4. Dose-response functions for mortality and morbidity.

\begin{tabular}{|c|c|}
\hline & Dose-response functions \\
\hline \multicolumn{2}{|l|}{ Mortality } \\
\hline Mortality due to short-term exposure to $\mathrm{PM}_{10}$ (under 5) & $\exp \left[\beta\left(\mathrm{x}-\mathrm{x}_{0}\right)\right]$ (a) \\
\hline Cardiopulmonary mortality related to long-term exposure to $\mathrm{PM}_{2.5}$ (over 30 years old) & {$\left[(\mathrm{x}+1) /\left(\mathrm{x}_{0}+1\right)\right]^{\beta}(\mathrm{b})$} \\
\hline Lung cancer mortality related to long-term exposure to $\mathrm{PM}_{2.5}$ (over 30 years old) & {$\left[(\mathrm{x}+1) /\left(\mathrm{x}_{0}+1\right)\right]^{\beta}(\mathrm{c})$} \\
\hline \multicolumn{2}{|l|}{ Morbidity } \\
\hline Chronic bronchitis (per 100,000 adults) & 0.9 \\
\hline Respiratory hospital admissions (per 100,000 people) & 1.2 \\
\hline Emergency room visits (per 100,000 people) & 23.5 \\
\hline Restricted activity days (per 100,000 adults) & 5750 \\
\hline Lower respiratory illness (per 100,000 children) & 169 \\
\hline Respiratory symptoms (per 100,000 adults) & 18,300 \\
\hline
\end{tabular}

Sources: [27] for mortality-related functions; [28-30] for morbidity-related functions. Notes: $\beta$ ranges between 0.0006 and 0.0010 for (a), 0.0562 and 0.2541 for (b), and 0.0562 and 0.2541 for (c); $\mathrm{x}=$ the current annual mean concentration of $\mathrm{PM}_{10}$ or $\mathrm{PM}_{2.5}\left(\mu \mathrm{g}\right.$ per $\left.\mathrm{m}^{3}\right)$; $\mathrm{x}_{0}=$ baseline concentration of $\mathrm{PM}_{10}$ or or $\mathrm{PM}_{2.5}(\mu \mathrm{g}$ per $\mathrm{m}^{3}$ ).

would result in 400 deaths. Thus, use of cleaner technologies (VSBK, HHK) would reduce current kiln-related premature mortality by $45-60$ percent.

Step 4. Measure health impacts. This step measures health impacts in physical and monetary terms. Physical valuation translates the cases of mortality and morbidity into DALYs. For mortality, the number of DALYs depends on the age at the time of death; however, on average, there are 80,000 DALYs lost per 10,000 cases of premature deaths. For morbidity, the number of DALYs lost per 10,000 cases varies according to the health endpoint: 22,000 for chronic bronchitis, 160 for respiratory hospital admissions, 45 for emergency room visits, 3 for restricted activity days, 65 for lower respiratory illnesses in children and 0.75 for respiratory symptoms $([22,23])$. As a result, the total loss per kiln is estimated at 5.5 DALYs for FCK, 2.8 for IFCK, 1.8 for VSBK and 1.6 for HHK.

The cost of health impacts from air pollution includes:

1) the monetary value of the DALYs lost. Using the human capital approach, the value of 1 DALY lost is estimated as the gross domestic product per capita or TK 93,500. Based on the Value of Statistical Life method, 1 DALY corresponds to TK620,000, after adjusting the estimate for the United States with the GDP per capita differences between United States and Bangladesh [24]. The analysis uses a range of TK93,500-620,000, averaging TK357,000 per DALY.

2) the direct cost of illness. This includes the direct cost of treating illnesses, the value of lost workdays, and the value of the time spent by caregivers with sick children. Interviews with Bangladesh health experts revealed estimates of the costs of hospitalization (TK1500 per day), doctor visits (TK400 per visit), and emergency visits (TK400 per visit).

Based on the above figures, Table 5 shows that the health cost of air pollution is highest for the FCK (TK0.9/ brick) and lowest for the VSBK (TK0.3/brick).

\subsubsection{Cost of $\mathrm{CO}_{2}$ Emissions}

This cost is based on the $\mathrm{CO}_{2}$ quantity emitted annually by each type of kiln and the average price on the carbon market. The annual $\mathrm{CO}_{2}$ emissions depends on the total brick production, the specific energy consumption, the IPCC default carbon-emission factor for fuel used, and the $\mathrm{CO}_{2}$ conversion factor [30]. Accordingly, Table 6 estimates that the FCK has the highest unit cost per brick (TK4.2), primarily because of the greatest value of specific coal consumption among the selected technologies. By contrast, low coal consumption makes the VSBK and the HHK the cleanest technologies in terms of $\mathrm{CO}_{2}$ emissions (TK2.5 per brick).

\subsubsection{Results of the Social Cost-Benefit Analysis}

The analysis shows that VSBK and HHK are the most socially profitable technologies, with net benefits of

Table 5. The health cost of air pollution per brick is highest for the FCK (2009).

\begin{tabular}{lcccc}
\hline \multirow{2}{*}{$\begin{array}{c}\text { Kiln } \\
\text { type }\end{array}$} & \multicolumn{2}{c}{ Annual health damages } & \multicolumn{2}{c}{ Present value of health damages } \\
\cline { 2 - 5 } & million TK/kiln & TK/brick & million TK/kiln & TK/brick \\
\hline FCK & 8.2 & 2.1 & 69 & 0.9 \\
IFCK & 4.2 & 1.1 & 35 & 0.5 \\
VSBK & 3.3 & 0.7 & 28 & 0.3 \\
HHK & 15.7 & 1.0 & 131 & 0.5 \\
\hline
\end{tabular}

*Over 20 years, $10 \%$ discount rate. 
Table 6. The cost of $\mathrm{CO}_{2}$ emissions per brick is highest for the FCK (2009).

\begin{tabular}{|c|c|c|c|c|}
\hline Factor & FCK & IFCK & VSBK & HHK \\
\hline Total brick production (thousand kg-bricks) ${ }^{\mathrm{a}}$ & 11,600 & 11,600 & 13,900 & 104,600 \\
\hline Coal per 100,000 bricks $(\mathrm{t})^{\mathrm{b}}$ & 22 & 15 & 13 & 13 \\
\hline Specific energy consumption $\left(\mathrm{TJ} / \mathrm{kg}\right.$-brick) ${ }^{\mathrm{c}}$ & 0.0019 & 0.0013 & 0.0012 & 0.0009 \\
\hline Carbon emission factor $(\mathrm{tC} / \mathrm{TJ})^{\mathrm{d}}$ & 25.8 & 25.8 & 25.8 & 25.8 \\
\hline Carbon to $\mathrm{CO}_{2}$ conversion factor & 3.6 & 3.6 & 3.6 & 3.6 \\
\hline $\mathrm{CO}_{2}$ per kiln per season $(t)^{\mathrm{e}}$ & 2100 & 1500 & 1500 & 4700 \\
\hline $\mathrm{CO}_{2}$ per100,000 bricks per season (t/100,000 bricks) & 53 & 36 & 35 & 31 \\
\hline Price $\mathrm{CO}_{2}(\mathrm{US} \$ / \mathrm{t})^{\mathrm{f}}$ & 13.5 & 13.5 & 13.5 & 13.5 \\
\hline Cost of $\mathrm{CO}_{2}$ emissions (thousand TK/kiln/year) & 2017 & 1375 & 1424 & 4451 \\
\hline Cost of $\mathrm{CO}_{2}$ emissions (TK/brick/year) & 0.50 & 0.34 & 0.30 & 0.30 \\
\hline Cost of $\mathrm{CO}_{2}$ emissions (TK/brick, present value) & 4.2 & 2.9 & 2.5 & 2.5 \\
\hline
\end{tabular}

Sources: ${ }^{a}[12]$; ${ }^{b}$ [5] for FCK, [11] for VSBK, [12] for HHK and 2009 field survey for IFCK; ${ }^{\circ}$ Estimated as specific coal consumption (kg/100,000 bricks) * calorific value $(\mathrm{TJ} / \mathrm{kg})$ * brick weight ( $\mathrm{kg} /$ brick); ${ }^{\mathrm{d}}[31]$; ${ }^{\mathrm{e}}$ Equals total brick production ${ }^{*}$ specific energy consumption * carbon emission factor * ${ }^{*}$ carbon to $\mathrm{CO}_{2}$ conversion factor. ${ }^{\mathrm{f}}[12]$.

Table 7. Results of the social cost-benefit analysis (present value, 20 years, $10 \%$, 2009).

\begin{tabular}{lcccc}
\hline \multicolumn{1}{c}{ Costs/benefits } & FCK & IFCK & VSBK & HHK \\
\hline Costs (million TK/kiln) & $\mathbf{2 0 0}$ & $\mathbf{1 5 1}$ & $\mathbf{1 3 9}$ & $\mathbf{5 3 6}$ \\
Investment cost & 4 & 7 & 6 & 56 \\
Cost of land & 1 & 1 & 1 & 3 \\
Cost of buildings & 0 & 0 & 1 & 9 \\
Operating costs & 109 & 95 & 92 & 300 \\
Health impacts of pollution & 69 & 35 & 28 & 132 \\
$\mathrm{CO}_{2}$ emissions & 17 & 12 & 12 & 37 \\
Benefits (million TK/kiln) & $\mathbf{1 9 8}$ & $\mathbf{2 0 0}$ & $\mathbf{2 1 4}$ & $\mathbf{7 4 6}$ \\
Net benefits (million TK/kiln) & $\mathbf{- 2}$ & $\mathbf{4 9}$ & $\mathbf{7 6}$ & $\mathbf{2 1 0}$ \\
Net benefits (TK/thousand bricks) & $\mathbf{- 3}$ & $\mathbf{4 3}$ & $\mathbf{7 5}$ & $\mathbf{6 8}$ \\
\hline
\end{tabular}

TK68-75 per thousand bricks. In contrast, the high costs of air pollution and $\mathrm{CO}_{2}$ emissions make the FCK socially unprofitable, causing net social costs of TK3 per thousand bricks.

\section{Sensitivity Analysis}

Table 8 presents a sensitivity analysis of net returns at different discount rates ( 2 and 5 percent). The results indicate that for any chosen discount rate, the HHK is the most profitable technology. FCK is the least attractive, and becomes unprofitable from the social viewpoint.

\section{Discussion}

It should be noted that the above analysis is subject to some limitations. First, it covers only a set of technologies for which data could be made available. Other technologies, though successful throughout the region,
Table 8. Estimated net benefits at changes in discount rates (TK/1000 bricks).

\begin{tabular}{cccc}
\hline & \multicolumn{3}{c}{ Discount rates (\%) } \\
\hline Private net benefits & $\mathbf{1 0}$ & $\mathbf{5}$ & $\mathbf{2}$ \\
FCK & 103 & 109 & 147 \\
IFCK & 107 & 127 & 172 \\
VSBK & 108 & 187 & 269 \\
HHK & 116 & 205 & 282 \\
Social net benefits & & & \\
FCK & -3 & -1 & -1 \\
IFCK & 43 & 53 & 73 \\
VSBK & 75 & 106 & 144 \\
HHK & 68 & 185 & 256 \\
\hline
\end{tabular}

could not be included, either because of lack of welldocumented information (e.g. Improved Zigzag) or because of their unlikely viability in Bangladesh (e.g. technologies based on non-fired bricks ${ }^{12}$ ). Therefore, the implications of this analysis refer only to the technologies covered by this paper.

Second, despite capturing a large portion of the impacts caused by brick kilns, the analysis does not include some effects, such as the impacts of air pollution on the value of real estate, on recreational areas, and on agricultural productivity. Thus, the present estimates should be regarded only as orders of magnitude.

Bearing in mind these limitations, the analysis points to some useful results. Figure 1 illustrates the net returns per thousand bricks for each technology for the entrepre-

\footnotetext{
${ }^{12}$ Non-fired bricks require material such as cement, sand and sometimes stone chips, which are not available in Bangladesh. The need to import raw material as well as equipment makes the business financially unattractive for the entrepreneurs.
} 


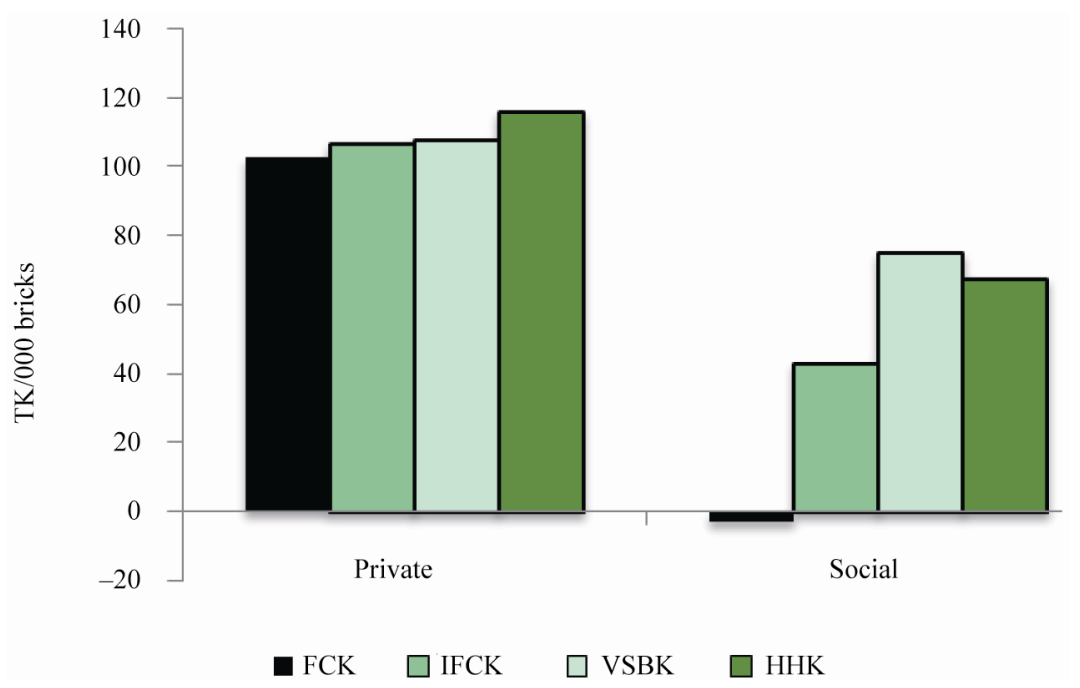

Figure 1. Net returns for the entrepreneur and for the society.

neur and for the society. Adopting cleaner technologies could increase the entrepreneur's profit from TK103 to TK116 per thousand bricks. When the costs of air pollution and $\mathrm{CO}_{2}$ emissions are factored in, traditional technologies become detrimental for the society: the value of the bricks is lower than the health costs imposed by making them. Cleaner technologies are the most desirable, with social net returns of TK68-75 per thousand bricks.

Better economic benefits from cleaner technologies is positive, but not enough by itself. Most brick entrepreneurs in Bangladesh can neither afford cleaner kilns, nor receive a loan to buy them. The next section provides some concrete recommendations for a more sustainable brick sector in Bangladesh.

\section{Conclusions and Recommendations}

In Bangladesh, brick sector is characterized by outdated technologies with low energy efficiency and high emissions, low mechanization rate and dominance of smallscale brick industries. This analysis shows that:

1) traditional polluting technologies are relatively profitable for the entrepreneur. However, when the costs of air pollution and $\mathrm{CO}_{2}$ emissions are factored in, they become undesirable for the society. Cleaner technologies stand out as the most socially profitable, with net returns of TK68-75 per thousand bricks.

2) replacing existing brick kilns with cleaner technologies would reduce the impact of brick pollution on premature mortality in Dhaka by $45-60$ percent.

3) the development of the brick sector in Bangladesh

\footnotetext{
${ }^{13}$ For example, through the Clean Air and Sustainable Environment (CASE) project and a grant from the Energy Sector Management Assistance Program (ESMAP), the World Bank is introducing clean technologies near Dhaka such as VSBK, Zig-Zags, HHKs and tunnel kilns. ${ }^{14}$ To make newer technologies more attractive, a carbon finance project will provide carbon benefits of $\$ 75,000$ per year to each HHK.
}

over the next 20 years should aim at: moving from traditional brick-making technologies (e.g. FCK) to cleaner ones (e.g. VSBK, HHK); diversifying products that are less energy intensive; increasing the proportion of largescale enterprises with higher capacity to adapt to cleaner technologies. To achieve these goals, a summary of concrete recommendations is provided below [6].

\subsection{In the Short Run}

- Recognize brick kilns as a formal industry. This would enable easier access to financial resources and improved working conditions.

- Create a Brick Technology Center. The center should disseminate information on new wall materials (e.g. perforated and hollow bricks), alternative raw materials and promote pilot projects of new technologies ${ }^{13}$.

- Facilitate the availability of subsidized credit lines to account for reduced health impacts from pollution and of other economic incentives supporting the production of new wall materials (e.g. via specific funds and preferential tax policies, as in China).

- Provide access to carbon markets, on account of the carbon emission reductions provided by cleaner technologies ${ }^{14}$.

\subsection{In the Medium Run}

- Enforce the existing regulations and policies, such as the ban of traditional high polluting kilns (e.g. FCK), particularly those located close to large population centers (e.g. Dhaka), upstream of the wind in the dry season, from November to April.

- Introduce regulations and policies that encourage adoption of cleaner technologies, such as revising emissions standards for brick kilns under ECR97 to 
make them technology independent and to encourage brick diversification (e.g. perforated or hollow bricks for partition walls).

\section{Acknowledgements}

The authors gratefully acknowledge the financial and technical support for this study provided by the World Bank's Energy Sector Management Asistance Program (ESMAP). Special thanks are given to Shakil A. Ferdausi, Dr. Khaliquzzaman and Jie Li for their contribution to this study.

\section{REFERENCES}

[1] International Labor Organization and World Trade Organization, "Globalization and Informal Jobs in Developing Countries," International Labor Organization and World Trade Organization, Geneva, 2009.

[2] Giri National Labor Institute, "Employment and Earnings in Urban Informal Sector-A Study on Arunachal Pradesh," National Labor Institute Series, No. 076/2007, 2007.

[3] A. Blackman, S. Newbold, J. Shih and J. Cook, "The Benefits and Costs of Informal Sector Pollution Control: Mexican Brick Kilns,” Discussion Paper 00-46, 2000. http://www.rff.org

[4] Ministry of Industries, "National Industrial Policy," Government of the People's Republic of Bangladesh, 2010.

[5] Bangladesh University of Engineering and Technology, "Small Study on Air Quality Impacts of the North Dhaka Brickfield Cluster by Modeling of Emissions and Suggestions for Mitigation Measures Including Financing Models," Chemical Engineering Department, Dhaka, 2007.

[6] World Bank, "Introducing Energy-Efficient Clean Technologies in the Brick Sector of Bangladesh," Report No. 60155-BD, Environment, Climate Change and Water Resource Unit, World Bank, Washington DC, 2010.

[7] B. A. Begum, S. K. Biswas and P. K. Hopke, "Key Issues in Controlling Air Pollutants in Dhaka," Atmospheric Environment, Vol. 45, No. 40, 2010, pp. 7705-7713.

[8] B. R. Gurjar, T. M. Butler, M. G. Lawrence and J. Lelieveld, "Evaluation of Emissions and Air Quality in Megacities," Atmospheric Environment, Vol. 42, No. 7, 2008, pp. 1593-1606.

[9] The Norwegian Institute for Air Research, "Bangladesh Air Pollution Management Project." http://bapman.nilu.no/

[10] Development Alternatives-Practical Action, "Brick Kilns Emission Management. Cleaner Technologies and Practices for Bangladesh Brick Sector," PHRD-Funded Initiative Submitted to CASE project, Final Report, 2009.

[11] U. Heirli, and S. Maithel, "Brick by Brick: The Herculean Task of Cleaning up the Asian Brick Industry," Swiss Agency for Development and Cooperation, 2008.

[12] World Bank, "Improving Kiln Efficiency in the Brick Making Industry in Bangladesh," Project Design Docu- ment Form, CDM-SSC-PDD, Version 04/03/11, World Bank, Washington DC, 2011.

[13] World Health Organization, Disability Adjusted Life Years.

http://www.who.int/healthinfo/global_burden_disease/me trics_daly/en/

[14] W. Kirsch, "Encyclopedia of Public Health," Springer, New York, 2008.

[15] P.-O. Johansson, "On the Definition and Estimation of the Value of a Statistical Life," Working Paper No. 2006-23, Milan European Economy Workshops, 2006.

[16] A. Khan, "Energy and Stack Emission Monitoring in Hybrid Hoffmann Kiln (HHK)," World Bank, Internal Report, Washington DC.

[17] S. Guttinkunda, "Impact Analysis of Brick Kilns on the Air Quality in Dhaka, Bangladesh," SIM-Air Working Paper Series, 2009. http://www.sim.org

[18] J. Meaud, "Eco-Design and Manufacturing Term Project: Optimization of Air Pollution," Final Report, University of Michigan, 2005.

[19] J. G. Watson, T. Zhu, J. C. Chow, J. Engelbrecht, E. M. Fujita and W. E. Wilson, "Receptor Modeling Application Framework Forparticle Source Apportionment," Chemosphere, Vol. 49, No. 9, 2002, pp. 1093-1136. doi:10.1016/S0045-6535(02)00243-6

[20] J. Cohen, H. R. Anderson, B. Ostro, K. Pandley, M. Krzyzanowski, N. Kunzli, K. Gutscmidt, C. A. Pope III, I. Romieu, J. M. Samet and K. Smith, "Urban Air Pollution," In: M. Ezzati, M. A. D. Rodgers, A. D. Lopez and C. J. L. Murray, Eds., Comparative Quantification of Health Risks: Global and Regional Burden of Disease Due to Selected Major Risk Factors, Vol. 2, World Health Organization, Geneva, 2004.

[21] Bangladesh Bureau of Statistics, "Statistical Pocketbook of Bangladesh," Planning Division, Ministry of Planning, 2009.

[22] B., Larsen, "Cost of Environmental Damage in Colombia: A Socio-Economic Study and Environmental Health Risk Assessment," Background Paper for Country Environmental Analysis, World Bank, Washington DC, 2004.

[23] K. Lvovsky, G. Hughes, D. Maddison, B. Ostro and D. W. Pearce, "Environmental Costs of Fossil Fuels: A Rapid Assessment Method with Application to Six Cities," Environment Department Paper No. 78, World Bank, Washington DC, 2000.

[24] United States Environmental Protection Agency. http://yosemite.epa.gov/ee/epa/eed.nsf/pages/MortalityRis $\mathrm{kV}$ aluation.html\#currentvsl

[25] E. Baum, "Black Carbon from Brick Kilns," Presentation for CleanAir Task Force, 2010.

[26] Ministry of Environment and Forests, "Comprehensive Industry Document with Emission Standards, Guidelines and Stack Height Regulation for Vertical Shaft Brick Kilns (VSBK) Vis-à-Vis Pollution Control Measures," COINDS/71/2007, Central Pollution Control Board, Ministry of Environment and Forests, New Delhi, 2007.

[27] C. A. Pope, R. T. Burnett, M. J. Thun, E. E. Calle, D. 
Krewski, K. Ito and G. Thurston, "Lung Cancer, Cardiopulmonary Mortality, and Long-Term Exposure to Fine Particulate Air Pollution," Journal of the American Medical Association, Vol. 287, No. 9, 2002, pp. 1132-1141. doi:10.1001/jama.287.9.1132

[28] S. Guttikunda, "Estimating Health Impacts of Urban Air Pollution," 2008. http://www.sim-air.org

[29] C. A. Pope and D. W. Dockery, "Health Effects of Fine Particulate Air Pollution: Lines That Connect," Journal of the Air Waste Management Association, Vol. 56, No. 6, 2006, pp. 709-742. doi: $10.1080 / 10473289.2006 .10464485$

[30] Health Effects Institute, "Health Effects of Outdoor Air Pollution in Developing Countries of Asia: A Literature Review," Health Effects Institute, Boston, 2004.

[31] Intergovernmental Panel on Climate Change, "Guidelines for National Greenhouse Gas Inventories," Intergovernmental Panel on Climate Change, 2006.

[32] L. Croitoru and M. Sarraf, "The Cost of Environmental Degradation. Case Studies from Middle East and North Africa," Directions in Development, World Bank, 2010. 